\title{
PENEGAKAN HUKUM ATAS PERKARA KARTEL DI LUAR PERSEKONGKOLAN TENDER DI INDONESIA
}

\author{
Veri Antoni
}

Departemen Hukum Dagang, Fakultas Hukum Universitas Gadjah Mada

Jalan Sosio Justisia No. 1, Bulaksumur, Sleman, D.I. Yogyakarta 55281

\begin{abstract}
Cartels are classified as serious violations of business competition law due to its impact on reductions in social welfare is considered very real. Almost two decades enforcement of cartels outside tender conspiracy, has not run optimally. There are several obstacles in its enforcement, as follows, business competition law does not recognize the existence of indirect evidence hence the practice of judicial practices has different point of views related to their position in the procedural law system. The Business Competition Law does not authorize search and seizure for Commission for the Supervision of Business (KPPU) to obtain documents as part of the verification process. The meaning of cartel as an agreement which stipulated in the Civil Code resulted in narrowed meaning of cartel, which is only limited to acts in the sense of agreement.
\end{abstract}

Keyword: cartel, law enforcement, obstacles, tender.

\section{Intisari}

Kartel dikategorikan sebagai pelanggaran berat dalam hukum persaingan usaha, karena dampaknya terhadap penurunan social welfare dianggap nyata. Hampir dua dekade penegakan kartel, khususnya kartel di luar persekongkolan tender, belum berjalan maksimal. Terdapat beberapa hambatan dalam penegakannya, antara lain, UU Persaingan Usaha tidak mengenal keberadaan indirect evidence, sehingga praktik peradilan pun memiliki perbedaan pandangan terkait kedudukannya dalam sistem hukum acara. UU Persaingan Usaha tidak memberikan kewenangan penggeledahan dan penyitaan bagi KPPU untuk memperoleh dokumen-dokumen sebagai bagian proses pembuktian. Pemaknaan kartel sebagai perjanjian sebagaimana diatur dalam KUH Perdata mengakibatkan terjadi penyempitan makna kartel yang hanya terbatas pada perbuatan dalam artian perjanjian saja.

Kata kunci: kartel, penegakan hukum, hambatan, tender.

\section{Pokok Muatan}

A. Pendahuluan 96

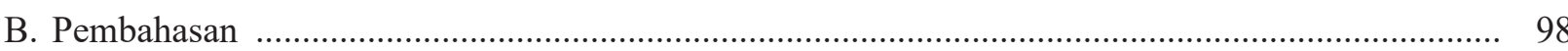

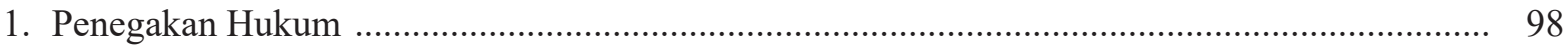

2. Kartel dan Karakteristik kartel ........................................................................................ 98

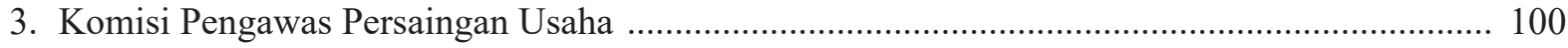

4. Hambatan dan Solusi dalam Penegakan Hukum atas Kartel ..................................................... 100

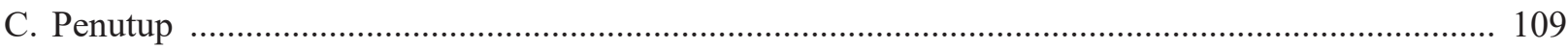

Alamat korespondensi: antoni.veri@ugm.ac.id. 


\section{A. Pendahuluan}

Dalam dunia usaha, persaingan menjadi penting karena ia dapat menjadi penggerak dunia usaha dan perekonomian untuk dapat tumbuh sehat. Ekonom memberikan argumentasi bahwa persaingan akan membuat harga ditentukan melalui mekanisme pasar, sehingga pelaku usaha terpacu melakukan inovasi produknya. Persaingan akan menghasilkan produk yang bervariatif dengan harga bersaing, yang pada akhirnya akan menguntungkan produsen maupun konsumen. ${ }^{1}$ Oleh karena begitu pentingnya persaingan, Amerika Serikat misalnya, melihat hukum persaingannya-Antitrust Law-, seperti Magna Carta bagi free enterprise untuk menjaga kebebasan ekonomi dan sistem free enterprise atau seperti Bill of Rights bagi Hak Asasi Manusia dalam rangka melindungi kebebasankebebasan pribadi yang sangat fundamental. ${ }^{2}$ Indonesia pun pada akhirnya, memiliki undangundang persaingan usaha, yaitu: Undang-Undang Nomor 5 Tahun 1999 tentang Larangan Praktik Monopoli dan Persaingan Usaha Tidak Sehat (selanjutnya disebut "UU No. 5 Tahun 1999").

Dalam perkembangan menjelang hampir dua dekade ini, keberadaan UU No. 5 Tahun 1999 telah memberikan banyak manfaat. Banyak kebiasaan yang menunjukkan bahwa perilaku dunia usaha cukup banyak berubah karena menyadari bahwa telah ada peraturan perundang-undangan dan KPPU (Komisi Pengawas Persaingan Usaha) yang mengawasi dunia usaha. ${ }^{3}$ Namun demikian, terlepas dari capaian positif KPPU tersebut, harus diakui juga bahwa untuk perkara-perkara tertentu, belum berjalan dengan maksimal. Salah satunya adalah perkara-perkara terkait kartel, khususnya kartel di luar persekongkolan tender.

Ketentuan kartel dalam UU No. 5 Tahun 1999 diatur dalam Pasal 5 (Penetapan Harga dan Penetapan Harga di Bawah Harga Pasar), Pasal 9
(Pembagian Wilayah), Pasal 10 (Pemboikotan), dan Pasal 11 (Kartel), serta Pasal 22 (Persekongkolan Tender). Sampai dengan Desember 2015 tercatat sejumlah perkara kartel di luar persekongkolan tender sebanyak 25 kasus atau sejumlah $9 \%$ dari total 272 perkara yang telah diputus oleh KPPU. Melihat jumlah perkara kartel di luar persekongkolan yang telah diputus oleh KPPU tersebut, jumlah perkara yang ditangani oleh KPPU sebanyak 25 dapat dikatakan tidak signifikan dilakukan selama rentang waktu 15 tahun. Hal ini mengingat laporan dugaan perilaku kartel yang masuk ke KPPU mencapai ratusan laporan. ${ }^{4}$ Sebagai perbandingan misalnya, the European Commission, dalam kurun waktu 2011 hingga Februari 2015 (selama empat tahun), telah berhasil memutuskan perkara kartel sebanyak 24 kasus, di antaranya kasus $T V$ dan computer monitor tubes pada tahun 2012, dengan nilai denda mencapai Rp. 21,3 trilliun. ${ }^{5}$ Lebih lanjut, terkait 25 perkara yang telah diputuskan oleh KPPU dijelaskan dalam tabel 1.

Merujuk tabel tersebut, dari 25 dugaan perkara yang telah diputus oleh KPPU tersebut, sebanyak tujuh perkara diputus oleh KPPU bahwa tidak terjadi pelanggaran kartel. Dengan demikian, 18 perkara yang diputus oleh KPPU terbukti secara sah dan meyakinkan terjadi pelanggaran kartel. Selanjutnya, dari 18 perkara yang diputus oleh KPPU terbukti secara sah dan meyakinkan adanya pelanggaran kartel dimana sebanyak delapan perkara tidak diajukan upaya keberatan oleh pelaku usaha (menerima putusan). Hal ini cukup menariknya bahwa pelaku usaha menerima putusan KPPU dan tidak mengajukan keberatan ke Pengadilan Negeri dikarenakan putusan KPPU tersebut tidak memberikan sanksi kepada pelaku usaha, meskipun pelaku usaha dinyatakan bersalah. Adapun sisanya yaitu sebanyak 10 perkara, terdapat upaya hukum keberatan oleh pelaku usaha dan upaya kasasi di

Rahmi Jened Parinduri Nasution, 2013, Interface Hukum Kekayaan Intelektual dan Hukum Persaingan (Penyalahgunaan HKI), RajaGrafindo Persada, Jakarta, hlm. 4

Sutan Rehmi Sjahdeini, "Larangan Praktik Monopoli dan Persaingan Usaha Tidak Sehat”, Jurnal Hukum Bisnis, Vol. 10, 2000. Ningrum Natasya Sirait, 2009, Hukum Persaingan Usaha di Indonesia dan Perkembangannya, CICODS (Centre for Intellectual Property, Competition, and Dispute Settlement), Fakultas Hukum, Universitas Gadjah Mada, Yogyakarta, hlm. 37. 
Tabel 1

Putusan KPPU Pelanggaran Kartel Dalam Upaya Hukum di PN (Pengadilan Negeri) dan MA (Mahkamah Agung)

(Periode 2000 - 31 Des 2015)

\begin{tabular}{|c|c|c|c|c|}
\hline No & Keterangan & $\begin{array}{c}\text { Jum- } \\
\text { lah }\end{array}$ & $\begin{array}{l}\text { To- } \\
\text { tal }\end{array}$ & $\begin{array}{c}\text { Persen- } \\
\text { tase }\end{array}$ \\
\hline & \multicolumn{4}{|l|}{ Di Tingkat KPPU } \\
\hline 1 & Tidak Terbukti di KPPU & 7 & 7 & $28 \%$ \\
\hline \multirow[t]{4}{*}{2} & Putusan Inkrach di KPPU & & 18 & $72 \%$ \\
\hline & Diterima Pelaku Usaha & 8 & & $44 \%$ \\
\hline & Dilawan Pelaku Usaha & 10 & & $64 \%$ \\
\hline & Total Jumlah Perkara & & 25 & \\
\hline \multirow[t]{8}{*}{3} & Upaya Hukum & & 10 & \\
\hline & Ditingkat Pengadilan Neger & & & \\
\hline & Putusan dikuatkan PN & 3 & & $30 \%$ \\
\hline & Putusan dibatalkan PN & 7 & & $70 \%$ \\
\hline & Ditingkat Mahkamah Agung & & & \\
\hline & c. Putusan dikuatkan MA & 3 & & $37 \%$ \\
\hline & d. Putusan dibatalkan MA & 5 & & $63 \%$ \\
\hline & e. Belum ada putusan MA & 2 & - & $25 \%$ \\
\hline
\end{tabular}

Sumber: Diolah penulis ${ }^{6}$ dari www.kppu.go.id

Mahkamah Agung. Dari 10 perkara yang diputus oleh KPPU secara sah dan meyakinkan, sebanyak tiga perkara dikuatkan oleh Putusan Pengadilan Negeri, sedangkan sisanya, yaitu sebanyak tujuh perkara dibatalkan oleh Pengadilan Negeri. Sementara itu, pada tingkat kasasi di Mahkamah Agung RI, dari 10 perkara tersebut, sebanyak tiga perkara yang dikuatkan oleh Mahkamah Agung, lima perkara dibatalkan oleh Mahkamah Agung, dan dua perkara sampai saat ini, masih dalam proses kasasi.

Dengan demikian, jika dibandingkan dengan pelanggaran-pelanggaran persaingan usaha lainnya, penegakan hukum atas perkara kartel di luar persekongkolan belum berjalan maksimal. Dilihat dari aspek kuantitas, dugaan pelanggaran kartel yang telah disidangkan oleh KPPU, yaitu sebanyak 25 perkara, adalah perkara kecil mengingat banyaknya, bahkan ratusan laporan ${ }^{7}$ dugaan perkara kartel kepada KPPU. Lebih lanjut, dari 25 perkara tersebut, hanya 11 perkara atau tidak lebih separuh perkara yang dapat dibuktikan oleh KPPU terjadinya perjanjian kartel, dimana sebagian besar yang terbukti pun adalah perkara-perkara yang kurang menyita perhatian masyarakat secara luas (baca: perkara kecil). ${ }^{8}$ Sementara untuk dugaan perkara kartel yang menimbulkan kerugian besar bagi konsumen seperti kartel di sektor barang konsumsi (kartel minyak goreng), di sektor perhubungan (dugaan kartel fuel surcharge), di sektor produksi (dugaan kartel semen), di sektor kesehatan (kartel obat), tidak terbukti pada tingkat Mahkamah Agung RI.

Belum efektifnya penegak an hukum terkait dengan praktik kartel adalah sesuatu yang tidak mengembirakan, mengingat kartel merupakan isu yang sangat penting dan fenomenal dalam penerapan hukum persaingan usaha di banyak negara. ${ }^{9}$ Kartel dianggap sebagai salah satu bentuk pembatasan

\footnotetext{
Selama ini KPPU telah menerima ratusan laporan dugaan persekongkolan tender, menahan pasokan dan kartel di beberapa komoditas dengan pola yang mirip satu sama lain. Lihat Muhammad Syarkawi Rauf, 2013, "Kartel dan Negara Gagal”, Bisnis Indonesia, 12 September 2013. Di tahun 2016 ini, terdapat juga beberapa perkara kartel yang telah diputusa oleh KPPU, diantara kartel ayam, tanggal 13 Oktober 2016, Nomor Perkara 02/KPPU-I/2016, pelanggaran terhadap Pasal 11 UU No. 5 Tahun 1999. SeLin itu, juga terdapat dugaan pelanggaran Pasal 5 UU No. 5 tahun 1999 dalam Industri Sepeda Motor Jenis Skuter Matik 110-125 CC di Indonesia oleh dua produsen besar (Yamahan dan Honda) dengan Nomor Perkara 04/KPPU-I/2016. “KPPU Gelar Sidang Perdana Dugaan Kartel Motor Matic", http://finance.detik.com/beritaekonomi-bisnis/d-3292654/kppu-gelar-sidang-perdana-dugaan-kartel-motor-matic, diakses 25 Oktober 2016.

Chandra Setiawan, "Memberantas Kartel: Menghadapi Perlawanan", dalam Komisi Pegawas Persaingan Usaha, Komitmen dari Harmoni, Lima Belas Tahun Implementasi Kebijakan Persaingan Usaha di Indonesia, Komisi Pengawas Persaingan Usaha, Jakarta, hlm. 152.

6 Diolah oleh penulis dari "Putusan Komisi Pengawasa Persaingan Usaha sejak tahun 2000 - 2015", http://www.kppu.go.idwww.kppu.go.id/, diakses 10 September 2016.

Selama ini KPPU telah menerima ratusan laporan dugaan persekongkolan tender, menahan pasokan dan kartel di beberapa komoditas dengan pola yang mirip satu sama lain. Lihat Muhammad Syarkawi Rauf, 2013, "Kartel dan Negara Gagal”, Bisnis Indonesia, 12 September 2013. Bandingkan misalnya dengan the European Commission, dalam kurun waktu 2011 hingga Februari 2015 (selama 4 tahun), telah berhasil memutuskan perkara kartel sebanyak 24 kasus, diantaranya kasus TV dan computer monitor tubes pada tahun 2012, dengan nilai denda mencapai Rp. 21.322.467.500.000. Chandra Setiawan, "Memberantas Kartel: Menghadapi Perlawanan”, dalam Komisi Pengawas Persaingan Usaha, Komitmen dari Harmoni, Lima Belas Tahun Implementasi Kebijakan Persaingan Usaha di Indonesia, Komisi Pengawas Persaingan Usaha, Jakarta, hlm. 152.

$9 \quad$ KPPU, "Sulitnya Membuktikan Praktik Kartel”, http://www.kppu.go.id/id/sulitnya-membuktikan-praktik-kartel/, diakses 4 Agustus 2011.
} 
persaingan usaha tertua sekaligus tindakan kolutif oleh pengusaha yang dianggap paling berbahaya dalam dunia bisnis. ${ }^{10}$ Kartel dikategorikan sebagai pelanggaran berat dari hukum persaingan usaha karena dampaknya terhadap penurunan social welfare dianggap sangat nyata, ${ }^{11}$ mengingat besarnya kerugian yang diderita oleh masyarakat.

Berdasarkan fakta-fakta empiris sebagaimana tersebut di atas, penulis tertarik untuk melihat lebih jauh, hal-hal apakah yang menjadi penyebab belum maksimalnya penegak an kartel di Indonesia? Dalam artian, apa saja hambatan-hambatan dalam penegak an kartel khususnya kartel di luar persekongkolan tender? Diakhir tulisan penulis juga memberikan saran-saran sebagai solusi yang dapat dilakukan untuk penegakan hukum yang lebih maksimal.

\section{B. Pembahasan}

\section{Penegakan Hukum}

Oleh Jimly Asshiddiqie, penegakan hukum diartikan sebagai upaya yang dilakukan untuk menjadikan hukum, baik dari arti formil yang sempit maupun dalam arti material yang luas, sebagai pedoman perilaku dalam setiap perbuatan hukum, baik oleh para subjek hukum yang bersangkutan maupun oleh aparatur penegakan hukum yang resmi diberi tugas dan kewenangan oleh undang-undang untuk menjamin berfungsinya norma-norma hukum yang berlaku dalam kehidupan bermasyarakat dan bernegara. ${ }^{12}$ Satjipto Rahardjo menyatakan bahwa penegakan hukum merupakan suatu usaha untuk mewujudkan ide-ide tentang kepastian hukum, kemanfaatan sosial dan keadilan menjadi kenyataan. Proses perwujudan ide-ide itulah yang merupakan hakikat dari penegak an hukum. ${ }^{13}$ Supaya penegak an hukum tersebut berjalan dengan efektif, menurut Soerjono Soekanto dipengaruhi oleh beberapa faktor, yaitu faktor hukum, faktor penegak hukum, faktor sarana atau fasilitas pendukung, dan faktor budaya masyarakat. ${ }^{14}$

Faktor hukum berkaitan dengan substansi materi hukum, yaitu materi yang terdapat dalam peraturan perundang-undangan, termasuk undangundang. Faktor peraturan perundang-undangan ini dapat menjadi kendala dalam penegakan hukum apabila, misalnya, tidak diikutinya asasasas berlakunya undang-undang, belum adanya peraturan pelaksana yang dibutuhkan untuk menerapkan undang-undang, adanya ketidakjelasan arti kata dalam undang-undang yang mengakibatkan multi tafsir ${ }^{15}$, serta ketidaklengkapan dari substansi undang-undang itu sendiri.

\section{Kartel dan Karakteristik kartel}

Istilah kartel berasal dari basaha Latin, yaitu cartellus, yang kemudian telah diterjemahkan ke dalam berbagai bahasa seperti Inggris dan Perancis menjadi cartel, Jerman menjadi kartell, dan Italia menjadi cartello. ${ }^{16}$ Dalam Black's Law Dictionary, kartel didefinisikan sebagai, "A combination of producers or sellers that join together to control a product's production or price. An association of firms with common interest, seeking to prevent extreme on unfair competition, allocate markets, or share knowledge". ${ }^{17}$ Lee McGowan menjelaskan bahwa, "cartels are a combination to divide up markets and fix prices (generally higher to maximise profit) among themselves. ${ }^{18}$ Keith N. Hylton menyatakan bahwa," A cartel is a group of firms that seeks to increase profit by restricting price and output competition among themselves. ${ }^{19}$ Richard

\footnotetext{
10 Tommi Ricky Rosandy, "Kartel dalam Hukum Persaingan Usaha”, http://tommirrosandy.wordpress.com/2011/03/26/kartel-dalam-hukumpersaingan-usaha/, diakses 4 Agustus 2010.

KPPU, "Sulitnya Membuktikan Praktik Kartel", Lot.cit.

Jimly Asshiddiqie, "Makalah Penegak Hukum”, http://www.jimly.com/makalah/namafile/56/Penegakan_Hukum.pdf, diakses 9 Juni 2018.

Raharjo Satjipto, 1987, Masalah Penegakan Hukum, Alumni, Bandung, hlm. 15.

Soerjono Soekanto, 2004, Faktor-Faktor yang Mempengaruhi Penegeakan Hukum, Cetakan Kelima, Raja Grafindo Persada, Jakarta, hlm. 19. Ibid.

Lee McGowan, 2010, The Antitrust Revolution in Eirope: Exploring The European Commision's Cartel Policy, Edward Elgar Publishing Limited, USA, hlm. 29.

Bryan A. Garner, 2004, Black's Law Dictionary: Eighth Editon, Thomson, West, USA, hlm. 227.

Lee McGowan, Op.cit., hlm. 31.

Keith N. Hylton, Antitrust Law: Economic Theory \& Common Law Evolution, Cambridge University Press, UK, hlm. 68.
} 
A. Posner menjelaskan bahwa kartel adalah, " $A$ contract among competing sellers to fix the price of the product they sell (or, what is the samething, to limit their output) is like any other contract in the sense that the parties would not sign it unless they expected it to make them all better of ${ }^{20}$ Komisi Eropa memberikan definisi kartel sebagai, "cartels are agreement and or concerted practices between two or more companies aimed at influencing the relevant parameters of competitions throuh practices such as the fixing of purchase or selling prices or other trading conditions, the allocation of production or sales quotas, the sharing of market including bid rigging. Ditambahkan juga bahwa, "the purpose of a cartel is to prevent, restrict or distort competition". ${ }^{21}$

Berdasarkan uraian-uraian pengertian kartel yang diberikan oleh para ahli sebagaimana tersebut di atas, dapat disimpulkan karakteristik dari perjanjian kartel adalah, pertama, perjanjian termasuk juga tindakan bersama (concerted action), yang dilakukan secara tertulis maupun tidak tertulis, dan bersifat sukarela, kedua, dilakukan oleh para pelaku usaha yang bersifat persaingan (bersifat horizontal) maupun pelaku usaha lainnya yang bersifat independen (bersifat vertikal), dan ketiga, bertujuan untuk mencegah, membatasi, ataupun mendistorsi persaingan di antara mereka.

Lebih jauh, Jurgita Bruneckiene, menyebutkan bahwa terdapat lima elemen secara umum yang dapat digunakan untuk mengambarkan perilaku kartel, yaitu: ${ }^{22}$

1. The number of independent firms ensuring collective market behaviour of legally unrelated firms.

2. Voluntary participation in a cartel expressing the will of the firms themselves to abide by the cartel agreement
3. Representation of the interest of firm showing that cartel member have a common goal;

4. A diversity of measures to pursue the goal, although price and output fixing are the most popular ones.

5. Transience of a cartel suggesting its dependence on internal and external condition of the cartel.

Selanjutnya, Jurgita Bruneckiene, memberikan contoh mengenai bentuk-bentuk dari perjanjian kartel, sebagai berikut: ${ }^{23}$

\section{Tabel 2}

\section{Bentuk-Bentuk Perjanjian Kartel}

\begin{tabular}{|c|c|}
\hline $\begin{array}{c}\text { Form } \\
\text { (Bentuk) }\end{array}$ & Example (Contoh) \\
\hline Verbal & $\begin{array}{l}\text { Lift cartel-regular meeting of } \\
\text { executives in public places, countryside } \\
\text { places, abroad to coordinate their } \\
\text { action verbally. }\end{array}$ \\
\hline Written & $\begin{array}{l}\text { Case of acrylic glass producers- } \\
\text { signing of the minutes of meeting; } \\
\text { peaceful settlements. }\end{array}$ \\
\hline $\begin{array}{l}\text { Unilateral } \\
\text { Decision }\end{array}$ & $\begin{array}{l}\text { Colgate \& Co, made a public } \\
\text { announcement that it would not sell its } \\
\text { product to distribution who supply the } \\
\text { product at lower than the set prices. }\end{array}$ \\
\hline Decision of & Case of Vereeniging \\
\hline Association & $\begin{array}{l}\text { Comenthandelelaren v. Commission- } \\
\text { the Court pointed out that "decision } \\
\text { of associations" do not necessarily } \\
\text { mean binding decisions, but also entail } \\
\text { recommendations to the members of } \\
\text { associations. }\end{array}$ \\
\hline $\begin{array}{l}\text { Concerted } \\
\text { Practices }\end{array}$ & $\begin{array}{l}\text { It is an informal form of cooperation of } \\
\text { economic entities whereby the entities } \\
\text { withdraw from their independent } \\
\text { practices in the market and adapt to } \\
\text { each other. }\end{array}$ \\
\hline Other Forms & Joint announcements/publicity. \\
\hline
\end{tabular}

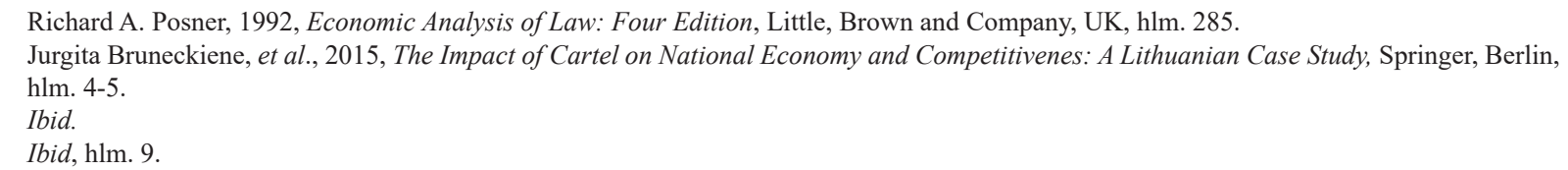


Motif pelaku usaha untuk melakukan tindakan kartel antara lain untuk mendapatkan keuntungan maksimal (maximum profit), dengan tidak menutup kemungkinan untuk mematikan new entrance (pemain baru) dengan menciptakan barrier to entry (hambatan masuk pasar). Akibat yang ditimbulkan adalah terciptanya praktik monopoli oleh para pelaku kartel sehingga secara perekonomian makro mengakibatkan inefisiensi alokasi sumber daya yang dicerminkan dengan timbulnya deadweight loss. $^{24}$

\section{Komisi Pengawas Persaingan Usaha}

Salah satu hal yang paling menarik dari UU No. 5 Tahun 1999 adalah adanya KPPU yang menjamin penegakan undang-undang tersebut. KPPU merupakan suatu lembaga yang independen yang terlepas dari pengaruh dan kekuasaan pemerintah serta pihak lain. ${ }^{25}$ Dalam melaksanakan fungsi dan tugasnya, berdasarkan Pasal 36 UU No. 5 Tahun 1999, KPPU diberikan kewenangan untuk: ${ }^{26}$

a. menerima laporan dari masyarakat dan atau dari pelaku usaha tentang dugaan terjadinya praktek monopoli dan atau persaingan usaha tidak sehat;

b. melakukan penelitian tentang dugaan adanya kegiatan usaha dan atau tindakan pelaku usaha yang dapat mengakibatkan terjadinya praktek monopoli dan atau persaingan usaha tidak sehat;

c. melakukan penyelidikan dan atau pemeriksaan terhadap kasus dugaan praktek monopoli dan atau persaingan usaha tidak sehat yang dilaporkan oleh masyarakat atau oleh pelaku usaha atau yang ditemukan oleh Komisi sebagai hasil penelitiannya;

d. menyimpulkan hasil penyelidikan dan/ atau pemeriksaan tentang ada atau tidaknya praktek monopoli dan/atau persaingan usaha tidak sehat; e. memanggil pelaku usaha yang diduga telah melakukan pelanggaran terhadap ketentuan undang-undang ini;

f. memanggil dan menghadirkan pelaku usaha, saksi, saksi ahli, atau setiap orang yang dianggap mengetahui pelanggaran terhadap undang-undang ini;

g. meminta bantuan penyidik untuk menghadirkan pelaku usaha, saksi, saksi ahli atau setiap orang sebagaimana dimaksud dalam huruf e dan $\mathrm{f}$, yang tidak bersedia memenuhi panggilan Komisi;

h. meminta keterangan dari instansi Pemerintah dalam kaitannya dengan penyelidikan dan atau pemeriksaan terhadap pelaku usaha yang melanggar ketentuan undang-undang ini;

i. mendapatkan, meneliti, dan atau menilai surat, dokumen, atau alat bukti lain guna penyelidikan dan atau pemeriksaan;

j. memutuskan dan menetapkan ada atau tidak adanya kerugian di pihak pelaku usaha lain atau masyarakat;

k. memberitahukan putusan Komisi kepada pelaku usaha yang diduga melakukan praktek monopoli dan atau persaingan usaha tidak sehat;

1. menjatuhkan sanksi berupa tindakan administratif kepada pelaku usaha yang melanggar ketentuan undangundang ini.

\section{Hambatan dan Solusi dalam Penegakan Hukum atas Kartel}

Sebagaimana disampaikan oleh Soerjono Soekanto bahwa salah satu faktor yang mempengaruhi penegakan hukum adalah faktor hukum, yaitu substansi hukum berupa peraturan perundang-undangan, termasuk undang-undang. Beranjak dari hal tersebut, substansi hukum yang dimaksud di sini adalah UU No. 5 Tahun 1999.

\footnotetext{
Ayudha D. Prayoga, "Kartel Dibangun untuk Maximum Profit", dalam Kompetisi, Edisi 39, 2013, Komisi Pengawas Persaingan Usaha, Jakarta, hlm. 15

25 Pasal 30 ayat (2) Undang-Undang Nomor 5 Tahun 1999 tentang Larangan Praktek Monopoli dan Persaingan Usaha Tidak Sehat. (Lembaran Negara Republik Indonesia Tahun 1999 Nomor 33, Tambahan Lembaran Negara Republik Indonesia Nomor 3817).

26 Pasal 36 Undang-Undang Nomor 5 Tahun 1999 tentang Larangan Praktek Monopoli dan Persaingan Usaha Tidak Sehat. (Lembaran Negara Republik Indonesia Tahun 1999 Nomor 33, Tambahan Lembaran Negara Republik Indonesia Nomor 3817).
} 
Merujuk pada UU No. 5 Tahun 1999 tersebut, berikut diuraikan hal-hal yang menjadi hambatan dalam penegakan pelanggaran kartel di Indonesia.

\section{a. Kelemahan Hukum Acara Terkait Kartel}

Berbeda dengan jenis-jenis pelanggaran hukum persaingan usaha lainnnya, penegak an hukum terkait praktik kartel adalah tidak mudah, bahkan dianggap sulit. Oleh karenanya, dalam penegak annya terdapat perbedaan karakteristik dalam penanganan perkaranya. Lebih jauh, tidak mengherankan jika kemudian di tahun 2006 misalnya, OECD (Organisation for Economic Co-operation and Development) mengadakan Global Forum, yang secara khusus menyoroti pembuktian kartel dan yang kemudian mengeluarkan sebuah laporan yang berjudul "Policy Roundtables: Prosecuting Cartels without Direct Evidence". ${ }^{27}$

Dalam konteks penegakan hukum, pembuktian merupakan bagian yang sangat penting, dan itu, tidak terkecuali dalam kartel. Van Bummulen dan Moeljatno, menjelaskan bahwa pembuktian atau membuktikan adalah memberikan kepastian yang layak menurut akal (redelijk) tentang: (a) apakah hal yang tertentu itu sungguh-sungguh terjadi dan (b) apa sebabnya demikian ${ }^{28}$. Untuk kegiatan pembuktian tersebut diperlukan adanya alat bukti. Ketentuan Pasal 42 UU No. 5 Tahun 1999 menyebutkan bahwa alat bukti pemeriksaan KPPU terdiri dari keterangan saksi; keterangan ahli; surat dan atau dokumen; petunjuk; dan keterangan pelaku usaha.

Pembuktian kartel seringkali terhambat karena otoritas persaingan usaha mengalami kesulitan dalam membuktikan eksistensi adanya kartel, yaitu menemukan bukti adanya perjanjian dimana pelaku usaha saling bersepakat untuk melakukan kartel. Para pelaku usaha seringkali membuat perjanjian kartel secara tidak tertulis sehingga tidak terdapat bukti fisik atau bukti langsung (direct evidence) mengenai kejahatan kartel yang mereka lakukan. Sifat kartel yang sangat rahasia inilah yang menjadikan kartel sebagai salah satu kejahatan di bidang persaingan usaha yang sangat sulit dideteksi di dunia. ${ }^{29}$ Oleh karenanya, mengingat sulitnya memperoleh perjanjian secara langsung (perjanjian), maka di banyak negara diperkenalkan adanya bukti tidak langsung (indirect evidence), yang meliputi alat bukti ekonomi dan alat bukti komunikasi.

Namun dalam konteks Indonesia, penggunaan indikasi-indikasi ekonomi maupun komunikasi tersebut sebagai alat bukti terjadinya pelanggaran kartel, tidak dikenal dalam UU No. 5 Tahun 1999 maupun sistem Hukum Acara Indonesia secara umum, baik Hukum Acara Perdata maupun Hukum Acara Pidana. Akibatnya, dalam praktik pengadilan terjadi perbedaan penyikapan terkait kedudukan indirect evidence ini. Pengadilan Negeri dalam banyak putusannya menolak keberadaan alat bukti indirect evidence sementara Mahkamah Agung, bersikap ada yang menolak namun ada juga yang menerima. Berikut diberikan sikap pengadilan menyikapi kedudukan indirect evidence dalam penegakan kartel di Indonesia sebagaimana diungkapkan oleh Binoto Nadapdap.

Policy Rouddtables: Prosecuting Cartels without Direct Evidence 2006, Global Forum, OCDC (Organisation for Economic Co-operation and Development).

28 Alfitra, 2011, Hukum Pembuktian Dalam Beracara Pidana, Perdata, dan Korupsi di Indonesia, Raih Asa Sukses, Jakarta, hlm. 22.

29 Policy Rouddtables: Prosecuting Cartels without Direct Evidence 2006, Op.cit, hlm. 5. 
Tabel 3

Sikap Pengadilan Terkait Penggunaan Indirect Evidence oleh Pengadilan Negeri dan Mahkamah Agung RI

\begin{tabular}{|c|c|c|c|c|}
\hline & \multicolumn{4}{|c|}{ Sikap Pengadilan Yang Menolak Penggunaan Alat Bukti Tidak Langsung (Indirect Evidence) ${ }^{30}$} \\
\hline No & Putusan KPPU & $\begin{array}{l}\text { Jenis Indirect } \\
\text { Evidence }\end{array}$ & $\begin{array}{l}\text { Alasan Penolakan oleh } \\
\text { Pengadilan Negeri }\end{array}$ & $\begin{array}{l}\text { Alasan Penolakan oleh } \\
\text { Mahkamah Agung }\end{array}$ \\
\hline 1 & $\begin{array}{l}\text { Putusan KPPU No. } \\
\text { 03/KPPU-I/2002 } \\
\text { tentang perkara } \\
\text { penjualan saham PT. } \\
\text { Indomobil Sukses } \\
\text { International }\end{array}$ & $\begin{array}{l}\text { - Dokumen tender } \\
\text { yang mirip } \\
\text { - Pilihn kata } \\
\text { - Format surat sama } \\
\text { - Pesan yang sama } \\
\text { - Formulasi surat } \\
\text { mengikuti urutan } \\
\text { yang sama } \\
\text { - Usulan mark up sama } \\
\text { - Cover letter sama. }\end{array}$ & $\begin{array}{l}\text { Pengadilan Negeri tidak } \\
\text { mempertimbangkan } \\
\text { penggunaan alat bukti } \\
\text { tidak langsung karena } \\
\text { yang dipertimbangkan } \\
\text { adalah soal kewenangan } \\
\text { KPPU mencantumkan } \\
\text { irah-irah, "Demi Keadilan } \\
\text { Berdasarkan Ketuhanan } \\
\text { Yang Masa Esa. } \\
\text { Pokok perkara belum } \\
\text { diperiksa. }\end{array}$ & $\begin{array}{l}\text { Mahkamah Agung tidak } \\
\text { mempertimbangkan } \\
\text { penggunaan alat bukti } \\
\text { tidak langsung karena } \\
\text { yang dipertimbangkan } \\
\text { adalah soal kewenangan } \\
\text { KPPU mencantumkan } \\
\text { irah-irah, "Demi Keadilan } \\
\text { Berdasarkan Ketuhanan } \\
\text { Yang Masa Esa. } \\
\text { Pokok perkara belum } \\
\text { diperiksa. }\end{array}$ \\
\hline 2 & $\begin{array}{l}\text { Putusan KPPU No. } \\
\text { 024/KPPU-I/2009 } \\
\text { tentang Perkara } \\
\text { Minyak Goreng. }\end{array}$ & $\begin{array}{l}\text { - Price parallelism; } \\
\text { - Communication } \\
\text { evidence berupa } \\
\text { pertemuan dan atau } \\
\text { komunikasi antar } \\
\text { pesaing meskipun } \\
\text { tidak terdapat } \\
\text { substansi pertemuan. } \\
\text { - Facilitating practices } \\
\text { yang dilakukan } \\
\text { melalui proses } \\
\text { signaling }\end{array}$ & 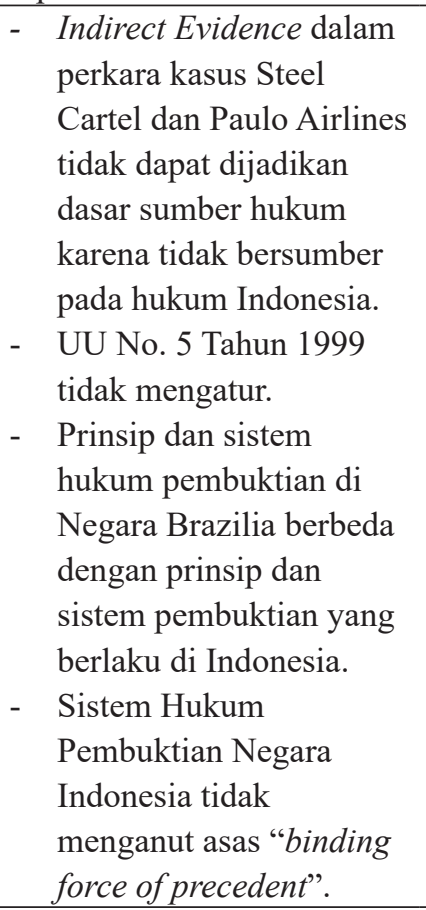 & 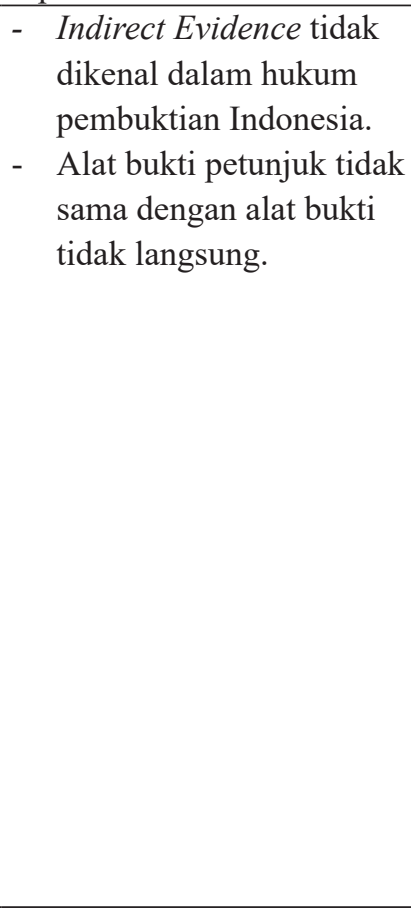 \\
\hline 3 & $\begin{array}{l}\text { Putusan KPPU No. } \\
\text { 25/KPPU-I/2009 } \\
\text { tentang Penetapan } \\
\text { Harga Fuel } \\
\text { Surcharge Dalam } \\
\text { Industri Jasa } \\
\text { Penerbangan } \\
\text { Domestik. }\end{array}$ & $\begin{array}{l}\text { - Perjanjian tidak } \\
\text { tertulis } \\
\text { - Besaran fuel } \\
\text { surcharge sama } \\
\text { - Uji korelasi dan } \\
\text { homogenity variance } \\
\text { test. } \\
\text { - Pembatalan perjanjian } \\
\text { tidak tertulis } \\
\text { - Trend kenaikan fuel } \\
\text { surchage yang sama. }\end{array}$ & $\begin{array}{l}\text { - Perubahan fuel surcharge } \\
\text { tidak dapat dipastikan } \\
\text { sebagai akibat adanya } \\
\text { kesepakatan perjanjian; } \\
\text { - } \\
\text { Tidak terbukti adanya } \\
\text { kesepakatan } \\
\text { - } \\
\text { Salah satu unsur Pasal } \\
5 \text { UU No. } 5 \text { Tahun } 1999 \\
\text { tidak terpenuhi, yaitu } \\
\text { adanya kesepakatan. }\end{array}$ & $\begin{array}{l}\text { - Judex factie tidak salah } \\
\text { menerapkan hukum; } \\
\text { - } \\
\text { Tidak terbukti adanya } \\
\text { kartel. }\end{array}$ \\
\hline
\end{tabular}

30 Binoto Nadapdap, 2015, Penerapan Pembuktian Tidak Langsung (Indirect Evidence) dalam Penanganan Perkara Kartel pada Komisi Pengawas Persaingan Usaha, Disertasi, Universitas Indonesia, Jakarta, hlm. 403-404. 


\begin{tabular}{|c|c|c|c|c|c|}
\hline 4 & $\begin{array}{l}\text { Putusan KPPU No. } \\
\text { 017/KPPU-I/2010 } \\
\text { tentang Perkara } \\
\text { Industri Farmasi } \\
\text { Kelas Terapi } \\
\text { Amlodipine. }\end{array}$ & $\begin{array}{l}\text { - Paraleling pricing } \\
\text { - Ada perintah untuk } \\
\text { berkomunikasi } \\
\text { diantara sesama } \\
\text { pesaing } \\
\text { - Adanya komunikasi } \\
\text { untuk mengatur } \\
\text { produksi, harga, dan } \\
\text { kuota. }\end{array}$ & & $\begin{array}{l}\text { Alat bukti tidak langsung } \\
\text { tidak dikenal dalam } \\
\text { hukum pembuktian } \\
\text { Indonesia; } \\
\text { Alat bukti tidak langsung } \\
\text { tidak diatur dalam } \\
\text { hukum Indonesia } \\
\text { Bukti luar negeri tidak } \\
\text { dapat dipakai sebagai } \\
\text { bukti. }\end{array}$ & $\begin{array}{l}\text { - Alat bukti tidak langsung } \\
\text { tidak sama dengan alat } \\
\text { bukti petunjuk } \\
\text { - } \quad \text { Supply Agreement dan } \\
\text { Distributor Agreement } \\
\text { tidak bertentangan } \\
\text { dengan UU Persaingan } \\
\text { - } \text { Berkomunikasi di antara } \\
\text { sesama pesaing tidak } \\
\text { dilarang. }\end{array}$ \\
\hline
\end{tabular}

\begin{tabular}{|c|c|c|c|c|}
\hline \multicolumn{5}{|c|}{ Sikap Pengadilan Yang Menerima Alat Bukti Tidak Langsung ${ }^{31}$} \\
\hline No & Putusan KPPU & $\begin{array}{l}\text { Jenis Indirect } \\
\text { Evidence }\end{array}$ & $\begin{array}{l}\text { Alasan Penolakan oleh } \\
\text { Pengadilan Negeri }\end{array}$ & $\begin{array}{l}\text { Alasan Penerimaan oleh } \\
\text { Mahkamah Agung }\end{array}$ \\
\hline 1 & $\begin{array}{l}\text { Putusan No. 02/ } \\
\text { KPPU-L/2009 } \\
\text { tentang Perkara } \\
\text { Tender Pekerjaan } \\
\text { Pembangunan } \\
\text { Jaringan Air Bersih } \\
\text { Kabupaten Lingga. }\end{array}$ & $\begin{array}{l}\text { - } \text { Bukti komunikasi } \\
\text { - Kesamaan form } \\
\text { dalam metode } \\
\text { pelaksanaan } \\
\text { - Kesalahan pengetikan } \\
\text { yang sama pada Bill } \\
\text { of Quantity } \\
\text { - Mempergunakan } \\
\text { alamat dan dokumen } \\
\text { yang sama } \\
\text { - Pengurus PT peserta } \\
\text { tender yang sama } \\
\text { - Mempergunakan } \\
\text { tenaga freelance yang } \\
\text { sama. }\end{array}$ & $\begin{array}{l}\text { - Alat bukti tidak langsung } \\
\text { tidak dikenal dalam UU } \\
\text { No. } 5 \text { Tahun } 1999 .\end{array}$ & $\begin{array}{l}\text { - Persekongkolan tender } \\
\text { dianggap cukup apabila } \\
\text { ditemukan beberapa } \\
\text { petunjuk dan bukti tidak } \\
\text { langsung. } \\
\text { - } \text { Adanya plus factors } \\
\text { - } \text { Kesamaan form "metode } \\
\text { pelaksanaan". } \\
\text { - Kesamaan kesalahan } \\
\text { dalam pengetikan Bill of } \\
\text { Quantity. } \\
\text { - Perubahan peserta tender } \\
\text { dimiliki oleh pihak yang } \\
\text { sama. } \\
\text { - Menggunakan nomor } \\
\text { telepon dan fax yang } \\
\text { sama. } \\
\text { - Ada komunikasi } \\
\text { - Panitia memberikan } \\
\text { kelonggaran terhadap } \\
\text { salah satu peserta tender } \\
\text { yang seharusnya gugur. }\end{array}$ \\
\hline 2 & $\begin{array}{l}\text { No. 09/ } \\
\text { KPPU-L/2008 } \\
\text { tentang Perkara } \\
\text { Pengadaan Give } \\
\text { Away Haji Tahun } \\
\text { Anggaran } 2007 \text { di } \\
\text { PT. Garuda Indonesia }\end{array}$ & $\begin{array}{l}\text { - Ada kesepakatan } \\
\text { yang tidak sesuai } \\
\text { dengan kesepakatan } \\
\text { sebelumnya; } \\
\text { - Ada pertemuan di } \\
\text { antara peserta tender } \\
\text { tanggal } 13 \text { Juni } 2007 \\
\text { - Ada kesepakatan } \\
\text { untuk dalam harga } \\
\text { - Ada rekaman } \\
\text { pertemuan } \\
\text { - Ada kesepakatan } \\
\text { perubahan harga. }\end{array}$ & $\begin{array}{l}\text { - Alat bukti tidak langsung } \\
\text { tidak dikenal dalam } \\
\text { sistem hukum Indonesia. }\end{array}$ & $\begin{array}{l}\text { - } \begin{array}{l}\text { Suatu pelanggaran dapat } \\
\text { dinyatakan dengan }\end{array} \\
\text { beberapa alat bukti tidak } \\
\text { langsung; } \\
\text { - } \text { Ada transkrip } \\
\text { pertemuan; } \\
\text { - } \quad \text { Ada kesepakatan untuk } \\
\text { menentukan pemenang } \\
\text { - } \quad \text { Petunjuk serta } \\
\text { keterangan pengusaha } \\
\text { menjadi rujukan } \\
\text { berbagai fakta yang } \\
\text { terungkap dalam } \\
\text { persidangan. }\end{array}$ \\
\hline
\end{tabular}


Untuk tingkatan Mahkamah Agung RI, selain dua kasus kartel yang dikuatkan oleh Mahkamah Agung, sebagaimana tersebut dalam tabel di atas, terdapat satu kasus lagi, yaitu Putusan KPPU No. 08/ KPPU-I/2014 terkait dengan Perkara Kartel Ban. Dalam kasus ini, Mahkamah Agung RI dalam Putusannya No. 221/Pdt.SusKPPU/2016, berpendapat bahwa dalam praktik dunia bisnis kesepakatan mengenai harga, produksi, wilayah (cartel) maupun kesepakatan anti persaingan bukti-bukti yang bersifat tidak langsung diterima sebagai bukti sah sepanjang bukti tersebut adalah bukti yang cukup dan logis, serta tidak ada bukti lain yang lebih kuat yang dapat melemahkan bukti-bukti yang besifat langsung tersebut. ${ }^{32}$

Dengan demikian, jika merujuk data empiris sebagaimana tersebut di atas, penegakan hukum terhadap pelanggaran kartel di luar persekongkolan tender belum maksimal. Tidak maksimalnya upaya penegakan hukum kartel dikarenakan adanya kesulitan dalam proses pembuktian ketika dihadapkan pada fakta bahwa kondisi pasar Indonesia yang terkonsentrasi, bahkan disinyalir dikendalikan oleh para kartel adalah sesuatu yang mengkhawatirkan. Dalam struktur pasar Indonesia, sebagian besar masih bersifat oligopoli ${ }^{33}$. Industri manufaktur misalnya, yang dianggap sebagai jantung perekonomian Indonesia, permasalahan mendasar selama lebih dari satu dekade terakhir, adalah terletak pada struktur pasar yang bersifat sangat oligopolistik. ${ }^{34}$ Kondisi pasar yang bersifat oligopolistik yang menghasilkan perilaku kartel ini sedang terjadi di Indonesia. Pihak Komisi Pengawas Persaingan Usaha bahkan menjelaskan bahwa kondisi ekonomi di Indonesia telah dikendalikan oleh kartel, karena hanya dikuasai oleh segelintir orang. ${ }^{35}$ Lebih lanjut, perilaku kartel tersebut muncul semakin mengkhawatirkan karena menyasar sektor-sektor terkait hajat hidup masyarakat, misalnya sektor pangan: daging ayam, daging sapi, beras dan bawang.

Dalam perkembangan penegakan hukum kartel yang terjadi dewasa ini, hampir setiap negara mengakui keberadaan indirect evidence dalam penegakan kartel. Menjadi pertanyaan kemudian apakah indirect evidence tersebut dapat berdiri sendiri sebagai alat bukti atau harus didukung alat bukti lain? Menjawab pertanyaan ini ada sedikit variasi di antara berbagai negara. Brazil dalam perkara The Steel Cartel Case misalnya, meskipun mengakui keberadaan economic evidence, namun putusan CADE (Council for Economic Defense) tidak semata-mata berdasarkan pertimbangan economic evidence, tapi juga berdasarkan apa yang dikenal dengan "parallelism plus theory". ${ }^{36}$ Di Malaysia, penggunaan indirect evidence tidak dapat berdiri sendiri, harus didukung oleh alat bukti lainnya. ${ }^{37}$ Di Australia, untuk menentukan adanya kesepakatan (meeting of the mind) yang diharuskan dalam pembuktian adanya perjanjian yang melanggar hukum persaingan, bukti situasional (circumtances) bisa dipakai. Bukti ini dapat berupa petunjuk perbuatan paralel, petunjuk tindakan bersama-

\footnotetext{
Putusan Mahkamah Agung RI Nomor 221/Pdt.Sus-KPPU/2016.

Ika Akbarwati, "Mengenal Konsep Kartel di Pasar Oligopoli”, https://www.selasar.com/ekonomi/mengenal-konsep-kartel-di-pasar-oligopoli, diakses 13 Mei 2016.

34 Dodi Mantra, "Oligopoli dan revitalisasi Industri”, http://opinicetak.blogspot.co.id/2015/01/oligopoli-dan-revitalisasi-industri.html, diakses 13 Mei 2016.

Andi Irawan, "Lagi tentang Kartel Pangan”, Media Indonesia, 2 Maret 2013.

Policy Rouddtables: Prosecuting Cartels without Direct Evidence 2006, Op.cit., hlm. 85.

Safinaz Mohammad Husein, Seminar Nasional: "Unfair Competition in Cyber Space: Comparative Perspectives from Indonesia Malaysia", Malang, 15 Mei 2012.
} 
sama, petunjuk adanya kolusi, petunjuk adanya struktur harga yang serupa (dalam kasus price fixing). Namun demikian, dalam pembuktiannya tetap memerlukan barang bukti langsung. Dengan demikian, apabila indirect evidence digunakan, kedudukannya hanyalah sebagai pendukung atau penguat dari salah satu alat bukti yang dimaksud. ${ }^{38}$

Berbeda dengan Brazil dan Malaysia, Republik Czech, dalam kasus Concerted Practise of Bakery Producers, menggunakan indirect evidence sebagai satu-satunya alat bukti. ${ }^{39}$ Sementara itu Amerika Serikat, dalam kasus High Fructose Corn Syrup yang membuktikan persekongkolan hanya dengan menggunakan bukti tidak langsung, sedangkan dalam kasus Baby Food, Blomkest Fertilizer, dan Williamson Oil adanya bukti langsung dianggap belum cukup untuk membuktikan adanya perse kongkolan. ${ }^{40}$

Meskipun terdapat perbedaan pandangan di berbagai negara, namun secara umum di banyak negara, inderect evidence cenderung harus didukung oleh alat-alat bukti yang lain, misalnya, alat bukti langsung. Hal tersebut menjadi penting, khususnya, untuk indirect evidence berupa economic evidence, mengingat pendekatan ekonomi merupakan kebalikan dari teori hukum. Pendekatan ekonomi bergantung pada model dan asumsi, bahkan dapat membuat hasil yang berbeda. Sementara itumateriil, asumsi ataupun model tidak diperbolehkan karena yang dicari adalah kebenaran yang bersifat materiil.$^{41}$

Kendala lain dalam upaya penegakan hukumkarteladalah keterbatasan kewenangan KPPU, khususnya terkait penggeledahan dan penyitaan. Mencermati kewenangan KPPU sebagaimana tersebut dalam Pasal 36 UU No. 5 Tahun 1999 tidak memberikan kewenangan tersebut (penggeledahan dan penyitaan). Berdasarkan Pasal tersebut, wewenang KPPU adalah melakukan penyelidikan dan atau pemeriksaan, meminta keterangan dari instansi Pemerintah dalam kaitannya dengan penyelidikan dan atau pemeriksaan terhadap pelaku usaha yang melanggar ketentuan undang-undang ini. Artinya, UU No. 5 Tahun 1999 tidak memberikan wewenang untuk menggeledah dan menyita sebagai bagian penting dalam proses pemeriksaan perkara.

Tidak adanya kewenangan terkait dengan penggeledahan dan penyitaan ini, membuat KPPU dalam melaksanakan tugasnya belum dapat berjalan maksimal. Apalagi, KPPU juga seringkali terkendala dengan sifat kerahasiaan perusahaan dalam mendapatkan data perusahaan yang diindikasikan melakukan pelanggaran kartel. Data perusahaan yang termasuk alat bukti surat dan atau dokumen sangat diperlukan KPPU dalam melakukan penyelidikan dan atau pemeriksaan. Pasal 41 UU No. 5 Tahun menyatakan bahwa pelaku usaha atau pihak lain yang diperiksa oleh KPPU terkait praktik monopoli dan persaingan usaha tidak sehat wajib menyerahkan alat bukti yang diperlukan. Namun demikian, tidak adanya ancaman bagi pelaku usaha atau pihak lain yang tidak menyerahkan dokumen atau alat bukti lain membuat KPPU kesulitan dalam melaksanakan tugas dan wewenangnya.

Sebagai perbandingan di negaranegara lain, otoritas persaingan usaha

\footnotetext{
Policy Rouddtables: Prosecuting Cartels without Direct Evidence 2006, Op.cit., hlm. 189.

Ibid, hlm. 85 dan 107.

Riris Munadiya, "Bukti Tidak Langsung (Indirect Evidence) dalam Penangganan Kasus Persaingan Usaha", Jurnal Persaingan Usaha, Komisi Pengawas Persaingan Usaha, Edisi 5, Tahun 2011, hlm. 188-189.

${ }^{41}$ Hal ini dengan pertimbangan bahwa hukum persaingan usaha lebih cenderung kepada ranah hukum publik dimana kerugian publik yang diderita akibat tindakan kartel yang terjadi di beberapa negara diidentifikasi sebagai bentuk dari tindak pidana. Dalam logika hukum publik, kebenaran materiil lebih dikedepankan dibandingkan dengan kebenaran formil.
} 
setempat diberikan kewenangan tersebut. Jepang misalnya, otoritas persaingannya, Japan Trade Commission (JFTC), memiliki kewenangan seperti memerintahkan orang yang terlibat dengan tuduhan untuk hadir, dan menyerahkan laporan dalam penelitian, pemeriksaan dan penyidikan, memasuki tempat-tempat manapun dari pelaku usaha yang terlibat kasus, atau tempat-tempat lainnya yang dianggap perlu untuk memeriksa aktivitas bisnis dan kekayaan perusahaan, pembukuan atau dokumen lainnya. ${ }^{42}$ Dalam penyidikan adanya kartel, JFTC bahkan dapat melakukan on the spot investigation, yakni penyelidikan secara mendadak di tempattempat pelaku usaha dan dapat memaksa pelaku usaha untuk menyerahkan dokumendokumen yang relevan. ${ }^{43}$

Pun begitu dengan Australia, juga memilikikewenanganuntukmemasukitempat manapun dan untuk memeriksa dokumen yang dimiliki atau dikuasai oleh seseorang dan memperbanyak (copy) atau meringkas dokumen-dokumen tersebut. ${ }^{44}$ Sedikit berbeda dengan Jerman, Bundeskartellamnt mempunyai wewenang untuk melakukan penggeledahan untuk mendapatkan dokumen atau bukti-bukti yang diperlukan dalam proses penyelidikan berdasarkan perintah hakim Pengadilan Negeri. ${ }^{45}$ Selain itu, Bundeskartellamnt mempunyai wewenang untuk melakukan penyitaan terhadap suatu objek apabila hal tersebut dianggap perlu untuk kepentingan penyelidikan dan tiga hari setelahnya Bundeskartellamnt harus meminta pengesahan barang sitaan tersebut kepada Pengadilan Negeri. ${ }^{46}$

\section{b. Penyempitan Makna Kartel dalam Hukum Positif Indonesia}

Ketentuan terkait kartel diatur dalam Pasal 5, Pasal 7, Pasal 9, Pasal 10, dan Pasal 11 UU No. 5 Tahun 1999 yang menyatakan bahwa kartel adalah perjanjian. Dalam Pasal 1 Angka 7 Undang-Undang a quo, dinyatakan bahwa "perjanjian adalah suatu perbuatan satu atau lebih pelaku usaha untuk mengikatkan diri terhadap satu atau lebih pelaku usaha lain dengan nama apapun, baik tertulis maupun tidak tertulis." Jika dicermati pengertian perjanjian sebagaimana tersebut dalam Pasal 1 Angka 7 Undang-Undang a quo hampir sama ketentuan Pasal 1313 KUH Perdata yang menyebutkan bahwa "Perjanjian adalah suatu perbuatan dengan mana satu orang atau lebih mengikatkan dirinya terhadap satu orang lain atau lebih."

Penggunaan definisi perjanjian sebagaimana diatur dalam KUH Perdata, menjadi masalah ketika dihadapkan pada bentuk-bentuk kartel sebagaimana disebutkan oleh Jurgita Bruneckiene, seperti unilateral decision (putusan sepihak), decision of association (putusan-putusan asosiasi), concerted practices (tindakan bersama), dan bentuk lainnya. Artinya, apakah bentuk-bentuk kartel yang demikian dapat dikategorikan sebagai perjanjian menurut KUH Perdata? Hal ini menjadi sangat penting mengingat, sebagaimana diungkapkan oleh Munir Fuady, bahwa hukum persaingan usaha di Indonesia, tidak mengenal "tacit agreement" atau perjanjian dengan "understanding". 47

Berdasarkan ketentuan Pasal 1313

42 Ernest Gellhorn and William Kovacic, 1994, Antitrust Law and Economics in a Nutshell, West Group, halaman 277, sebagaimana dikutip oleh Paripurna dalam "Cartel, Kendala dan Solusi Penegakan Hukumnya di Indonesi”, Seminar Nasional Kartel, Kendala dan Solusi Dalam Penegakannya di Indonesia” CICODS, Yogyakarta, hlm. 10.

44 Ibid.

45 Section 59 German Act Against Restraint of Competition.

46 Section 58, Ibid.

47 Munir Fuady, 2003, Hukum Anti Monopoli Menyongsong Era Persaingan Sehat, Jakarta, hlm. 51-52. 
KUH Perdata, "Perjanjian adalah suatu perbuatan dengan mana seorang atau lebih mengikatkan dirinya terhadap satu orang atau lebih." Pengertian perjanjian menurut KUH Perdata memiliki kelemahan, karena kata "mengikatkan" merupakan kata kerja yang sifatnya hanya datang dari satu pihak. Sementara itu, maksud dari perjanjian itu sendiri adalah para pihak saling mengikatkan diri. Oleh karenanya, pengertian perjanjian dalam Pasal 1313 KUH Perdata tersebut harus dimaknai adanya kehendak untuk saling mengikat diri secara bertimbal balik.

Sudikno Mertokusumo menyatakan perjanjian adalah hubungan hukum antara dua orang yang bersepakat untuk menimbulkan akibat hukum. ${ }^{48}$ Disebut hubungan hukum, karena di dalamnya terdapat dua perbuatan hukum yang dilakukan oleh dua orang atau lebih,yaituperbuatanpenawaranatauaanbond atau offer, dan penerimaan atau aanvararding atau acceptance. Sementara itu, Muhammad Syaifuddin, menyimpulkan bahwa perjanjian (kontrak), pertama, perbuatan hukum yang bertimbal balik dalam lapangan hukum harta kekayaan, kedua, hubungan antara kontrak dan perikatan adalah kontrak menimbulkan akibat hukum yang menimbulkan perikatan, ketiga, substansi atau isi kontrak, merupakan kesepakatan yang didasarkan oleh atas otoritas (kehendak bebas yang berdasarkan wewenang dan cakap melakukan perbuatan hukum) yang dimiliki oleh para pembuat kontrak, kecuali dalam batas-batas tertentu terdapat intervensi, baik dari undang-undang yang memaksa, ketertiban umum dan atau kesusilaan maupun otoritas hukum tertentu. ${ }^{49}$

Mengikat atau tidaknya suatu kontrak terhadap para pihak yang membuatnya tergantung kepada sah atau tidak sahnya kontrak yang dibuat para pihak tersebut. Sah atau tidaknya suatu kontrak dapat dipastikan dengan mengujinya mengunakan instrumen hukum yang terkonkritisasi dalam wujud syarat-syarat sahnya suatu kontrak sebagaimana diatur secara sistematis dalam Buku III KUH Perdata, yaitu: pertama, syarat sahnya suatu kontrak sebagaimana diatur dalam Pasal 1320 KUH Perdata, dan kedua, syarat sah suatu kontrak sebagaimana diatur di luar Pasal 1320 KUH Perdata, yaitu Pasal 1335 KUH Perdata, Pasal 1338 ayat (3) KUH Perdata, Pasal 1339 KUH Perdata, Pasal 1347 KUH Perdata. Salah satu syarat sah kontrak tersebut adalah adanya kata adanya kata sepakat sebagaimana diatur dalam Pasal 1320 KUH Perdata di samping cakap, obyek tertentu, dan kausa yang halal.

Adanya atau lahirnya kata sepakat atau kesepakatan merupakan hal yang penting dalam sebuah kontrak, karena tidak ada kontrak jika tidak ada kesepakatan. Namun demikian, KUH Perdata sendiri ternyata tidak memberikan penjelasan tentang arti kata sepakat. Menurut Sudikno Mertokusumo, kesepakatan adalah persesuaian penyataaan kehendak antara satu orang atau lebih dengan pihak lainnya. Yang sesuai itu adalah penyataannya, karena kehendak tidak dapat dilihat/diketahui orang lain. ${ }^{50}$ Kesepakatan dalam kontrak menurut J.H Niewenhuis, dibentuk oleh dua unsur, yaitu pertama, penawaran (aanbod, offerte, offer), yang diartikan sebagai pernyataan kehendak yang mengandung usul untuk mengadakan kontrak, yang mencakup essensialia (unsur mutlak yang harus ada) dalam kontrak yang ditutup; kedua, penerimaan (aanvarding, acceptatie, acceptance), yang artinya pernyataan setuju dari pihak lain yang ditawari. Kemudian,

48 Sudikno Mertokusumo, 1999, Mengenal Hukum Suatu Pengantar, Liberty, Yogyakarta, hlm. 118.

49 Muhammad Syaifuddin, 2012, Hukum Kontrak: Memahami Kontrak dalam Perspektif Filsafat, Teori, Dogmatik, dan Praktik Hukum (Seri Pengayaan Hukum Perikatan), Mandar Maju, Bandung, hlm. 113.

50 Ibid. 
dasar keterikatan kontraktual berasal dari pernyataan kehendak, yang dibedakan dalam dua unsur, yaitu kehendak (wills) dan pernyataan (verklaring). Ini berarti bahwa kehendak dan pernyataan adalah syarat terpenting dalam suatu konntrak. Herlien Budiono menjelaskan bahwa dalam kontrak penawaran-penerimaan, diisyaratkan adanya suatu kehendak yang nyata yang tertuju pada orang tertentu, yang terejawantahkan dalam pernyataan yang disampaikan oleh kedua belah pihak, yang terwujud dalam rangkaian kata-kata, baik secara lisan maupun tulisan. Kehendak dapat muncul dalam bentuk pernyataan secara tegas atau diam-diam, bahkan juga sikap berdiam diri atau tidak berbuat yang dalam keadaan tertentu dapat diartikan sebagai suatu pernyataan.

Menurut Sudikno Mertokusumo ${ }^{51}$ cara terjadinya persesuaian pernyataan kehendak, antara lain, bahasa yang sempurna secara lisan; bahasa yang tidak sempurna, asal dapat dimengerti dan diterima oleh pihak lawan; bahasa isyarat, asal dapat dimengerti dan diterima oleh pihak lawannya; dan atau diam atau membisu, asal dipahami atau diterima pihak lawan. Mendasarkan pada hal ini, maka bentuk-bentuk unilateral decision (putusan sepihak), decision of association (putusan asosiasi), concerted practices (tindakan bersama), dapat menjadi perjanjian apabila dalam peristiwa tersebut dapat dibuktikan adanya persesuaian kehendak antara para pelaku usaha. Sebaliknya, jika hal tersebut, tidak dapat dibuktikan, tindakan-tindakan tersebut tidaklah dapat dikategorikan sebagai perjanjian berdasarkan KUH Perdata.

Hal ini menjadi penting karena, dalam konteks perdata, dikenal adanya istilah lain, yaitu "gesamtakt", dalam Bahasa Jerman yang lazim diartikan atau diterjemahkan sebagai "perbuatan bersama". Gesamtakt atau tindakan bersama adalah kesepakatan yang diambil oleh sekelompok orang untuk menetapkan suatu keputusan tentang suatu hal dan keputusan tersebut, mengikat semua subjek hukum yang terlibat dalam pengambilan putusan tersebut atau semua anggota kelompok yang bersangkutan, misalnya, putusan rapat anggota perkumpulan, putusan rapat pemegang saham, putusan Dewan Perwakilan Rakyat dan putusan kabinet.

Dalam teori hukum perdata, keputusan rapat yang diambil baik melalui cara voting ataupun musyawarah, hasil keputusan rapat tidak dapat disebut perjanjian atau perikatan, namun disebut sebagai "gesamtakt" atau "perbuatan bersama", sehingga tidak tepat jika keputusan rapat masuk dalam kategori perjanjian. Konsekuensinya, jika menggunakan pendekatan perjanjian dalam KUH Perdata, maka terbentuknya kartel dalam bentuk unilateral dicision (putusan sepihak), decision of association (putusan asosiasi), concerted practices (tindakan bersama), pengumuman atau publikasi dalam bukti sinyal harga, tidaklah dapat dikatakan sebagai perjanjian. Sebagai salah satu contoh, adalah risalah rapat, oleh sebagian kalangan tidak dapat dikatakan sebagai perjanjian mengingat dalam suatu rapat jika memutuskan sesuatu, dimungkinkan ada beberapa pihak yang sebenarnya tidak setuju dengan keputusan rapat, namun tetap menandatang ani presensi atau daftar hadir dalam rapat. Selanjutnya, kembali kepada asas perjanjian, bahwa pihak yang mengadakan perjanjian harus sepakat dan mengikatkan dirinya pada isi perjanjian, sementara tidak semua yang hadir dalam rapat setuju dengan isi risalah rapat. Kadangkala, bahkan dilakukan voting untuk memutuskan suatu keputusan rapat karena ada pihak yang abstain dan ada yang 
tidak setuju.

Oleh karena itu, diperlukan perluasan makna perjanjian (agreement) kartel di luar makna perjanjian sebagaimana yang telah diatur dalam KUH Perdata. Artinya, makna kartel perlu diperluas tidak hanya sebatas perbuatan dalam artian perjanjian, tetapi lebih luas dari hal tersebut. Sebagai perbandingan misalnya, Amerika Serikat memaknai perjanjian kartel sebagaimana diungkapkan oleh Ernest Gellhorm bahwa perilaku monopolistik tidak harus menghasilkan sebuah perjanjian. Diungkapkan bahwa, "Attempted monopolization reaches direct interaction between firms in concentrated markets even though such interaction does not result in an agreement. ${ }^{52}$ Sementara itu, untuk Uni Eropa, memasukkan juga parallel behavior or conscious parallelism, tacit collusion (collectively hold a dominant position), sebagai bentuk kartel. ${ }^{53}$

\section{Penutup}

Berdasarkan uraian-uraian sebagaimana tersebut di atas, dapat disimpulkan bahwa di antara hambatan yang menjadi penyebab belum efektifnya penegak an kartel di Indonesia, adalah, pertama, UU No. 5 Tahun 1999 tidak mengenal adanya indirect evidence, sehingga praktik peradilan pun memiliki perbedaan pandangan terkait kedudukannya dalam sistem hukum acara yang berlaku di Indonesia. Mahkamah Agung RI dalam berbagai putusannya ada yang menerima indirect evidence dan ada juga yang menolaknya sebagai salah satu alat bukti. Kedua, UU No. 5 Tahun 1999 tidak memberikan kewenangan penggeledahan dan penyitaan bagi KPPU untuk memperoleh dokumen-dokumen yang diperlukan, baik pelaku usaha yang diduga melanggar maupun pihak-pihak terkait lainnya. Ketiga, pemaknaan kartel sebagai perjanjian sebagaimana diatur dalam KUH Perdata mengakibatkan terjadinya penyempitan makna kartel, yang hanya terbatas pada perbuatan dalam artian perjanjian. Perjanjian yang dimaksud dalam hal ini adalah perjanjian menurut KUH Perdata.

Lebih lanjut, sebagai saran kepada Pemerintah dan Dewan Perwakilan Rakyat (DPR) perlu mempertimbangkan perbaikan terhadap substansi UU No. 5 Tahun 1999 dengan menempatkan indirect evidence sebagai salah satu alat bukti dalam persaingan usaha. Selain itu, perlu dipertimbangkan mengenai perluasan kewenangan KPPU dalam melakukan pemeriksaan, termasuk adanya kewenangan untuk menggeledah dan menyita, serta memperluas makna kartel yang tidak terbatas pada perbuatan dalam artian perjanjian saja.

\section{DAFTAR PUSTAKA}

\section{A. Buku}

Alfitra, 2011, Hukum Pembuktian Dalam Beracara

Pidana, Perdata, dan Korupsi di Indonesia, Raih Asa Sukses, Jakarta.

Bruneckiene, Jurgita, et al., 2015, The Impact

of Cartel on National Economy and Competitivenes: A Lithuanian Case Study, Springer, Berlin.
Fuady, Munir, 2003, Hukum Anti Monopoli Menyongsong Era Persaingan Sehat, Jakarta.

Garner, Bryan A., 2004, Black's Law Dictionary: Eighth Editon, Thomson, West, USA.

Gellhorn, Ernest dan William Kovacic, 1994, Antitrust Law and Economics in a Nutshell, West Group, UK.

\footnotetext{
52 Ernest Gellhorn dan William Kovacic, 1994, Antitrust Law and Economics in a Nutshell, West Group, UK, hlm. 277. Lihat juga Paripurna Sugarda,"Cartel, Kendala dan Solusi Penegakan Hukumnya di Indonesi", Makalah, Seminar Nasional Kartel, Kendala dan Solusi dalam Penegakannya di Indonesia, CICODS (Centre for Intellectual Property, Competition, and Dispute Settlement) Fakultas Hukum, Universitas Gadjah Mada, 10 Mei 2017, Yogyakarta, hlm. 10.

53 Alison Jones dan Brenda Sufrin, 2004, EC Competition Law, Oxford University Press, Oxford. Lihat juga Paripurna Sugarda, Ibid.
} 
Hylton, Keith N., Antitrust Law: Economic Theory

\& Common Law Evolution, Cambridge University Press, UK.

Jones, Alison dan Brenda Sufrin, 2004, EC Competition Law, Oxford University Press, Oxford.

Komisi Pengawas Persaingan Usaha, Komitmen dari Harmoni, Lima Belas Tahun Implementasi Kebijakan Persaingan Usaha di Indonesia, Komisi Pengawas Persaingan Usaha, Jakarta. McGowan, Lee, 2010, The Antitrust Revolution in Eirope: Exploring The European Commision's Cartel Policy, Edward Elgar Publishing Limited, USA.

Mertokusumo, Sudikno, 1999, Mengenal Hukum Suatu Pengantar, Liberty, Yogyakarta.

Munadiya, Ernest, dan William Kovacic, 1994, Antitrust Law and Economics in a Nutshell, West Group.

Nasution, Rahmi Jened Parinduri, 2013, Interface Hukum Kekayaan Intelektual dan Hukum Persaingan (Penyalahgunaan HKI), RajaGrafindo Persada, Jakarta.

Posner, Richard A., 1992, Economic Analysis of Law: Four Edition, Little, Brown and Company, UK.

Satjipto, Raharjo, 1987, Masalah Penegakan Hukum, Alumni, Bandung.

Sirait, Ningrum Natasya, 2009, Hukum Persaingan Usaha di Indonesia dan Perkembangannya, CICODS (Centre for Intellectual Property, Competition, and Dispute Settlement), Fakultas Hukum, Universitas Gadjah Mada, Yogyakarta.

Soekanto, Soerjono, 2004, Faktor-Faktor yang Mempengaruhi Penegeakan Hukum, Cetakan Kelima, Raja Grafindo Persada, Jakarta.

Syaifuddin, Muhammad, 2012, Hukum Kontrak: Memahami Kontrak dalam Perspektif Filsafat, Teori, Dogmatik, dan Praktik Hukum (Seri Pengayaan Hukum Perikatan), Mandar Maju, Bandung.

\section{B. Artikel Jurnal}

Munadiya, Riris, "Bukti Tidak Langsung (Indirect Evidence) dalam Penangganan Kasus Persaingan Usaha", Jurnal Persaingan Usaha, Komisi Pengawas Persaingan Usaha, Edisi 5, Tahun 2011.

Nadapdap, Binoto, 2015, Penerapan Pembuktian Tidak Langsung (Indirect Evidence) dalam Penangganan Perkara Kartel pada Komisi Pengawas Persaingan Usaha, Disertasi, Universitas Indonesia, Jakarta.

Sjahdeini, Sutan Rehmi, "Larangan Praktik Monopoli dan Persaingan Usaha Tidak Sehat”, Jurnal Hukum Bisnis, Vol. 10, 2000.

\section{Makalah/Pidato}

Mohammad Husein, Safinaz, "Unfair Competition in Cyber Space: Comparative Perspectives from Indonesia Malaysia", Makalah, Seminar Nasional, Malang, 15 Mei 2012.

Policy Rouddtables: Prosecuting Cartels without Direct Evidence 2006, Global Forum, OCDC (Organisation for Economic Co-operation and Development).

Sugarda, Paripurna, "Cartel, Kendala dan Solusi Penegakan Hukumnya di Indonesi”, Makalah, Seminar Nasional Kartel, Kendala dan Solusi dalam Penegakannya di Indonesia, CICODS (Centre for Intellectual Property, Competition, and Dispute Settlement) Fakultas Hukum, Universitas Gadjah Mada, 10 Mei 2017, Yogyakarta.

\section{Artikel Majalah atau Koran}

Irawan, Andi, "Lagi tentang Kartel Pangan", Media Indonesia, 2 Maret 2013.

Prayoga, Ayudha D., "Kartel Dibangun untuk Maximum Profit", Kompetisi, Edisi 39, 2013, Komisi Pengawas Persaingan Usaha, Jakarta.

Rauf, Muhammad Syarkawi, 2013, "Kartel dan Negara Gagal”, Bisnis Indonesia, 12 September 2013. 


\section{E. Artikel Internet}

Akbarwati, Ika, "Mengenal Konsep Kartel di Pasar Oligopoli", https://www.selasar.com/ ekonomi/mengenal-konsep-kartel-di-pasaroligopoli, diakses 13 Mei 2016.

Asshiddiqie, Jimly, "Makalah Penegak Hukum", http://www.jimly.com/makalah/namafile/56/ Penegakan_Hukum.pdf, diakses 9 Juni 2018.

Detiknews, "KPPU Gelar Sidang Perdana Dugaan Kartel Motor Matic", http://finance.detik. com/berita-ekonomi-bisnis/d-3292654/kppugelar-sidang-perdana-dugaan-kartel-motormatic, diakses 25 Oktober 2016.

Mantra, Dodi, "Oligopoli dan Revitalisasi Industri", http://opinicetak.blogspot.co.id/2015/01/ oligopoli-dan-revitalisasi-industri.html, diakses 13 Mei 2016.

Rosandy, Tommi Ricky, "Kartel dalam Hukum Persaingan Usaha", http://tommirrosandy. wordpress.com $/ 2011 / 03 / 26 / \mathrm{kartel}$-dalam- hukum-persaingan-usaha/, diakses 4 Agustus 2010.

\section{F. PenegakanPeraturan Perundang-} undangan

Kitab Undang-Undang Hukum Perdata (KUH Perdata).

Undang-Undang Nomor 5 Tahun 1999 tentang Larangan Praktek Monopoli dan Persaingan Usaha Tidak Sehat. (Lembaran Negara Republik Indonesia Tahun 1999 Nomor 33, Tambahan Lembaran Negara Republik Indonesia Nomor 3817).

\section{G. Putusan Pengadilan}

Putusan Mahkamah Agung Nomor 221/Pdt.SusKPPU/2016.

\section{H. Dokumen Lain}

German Act Against Restraint of Competition. 